Prepared in cooperation with the city of De Soto, Missouri, and Jefferson County, Missouri

\title{
Flood-Inundation Maps for Joachim Creek, De Soto, Missouri, 2018
}

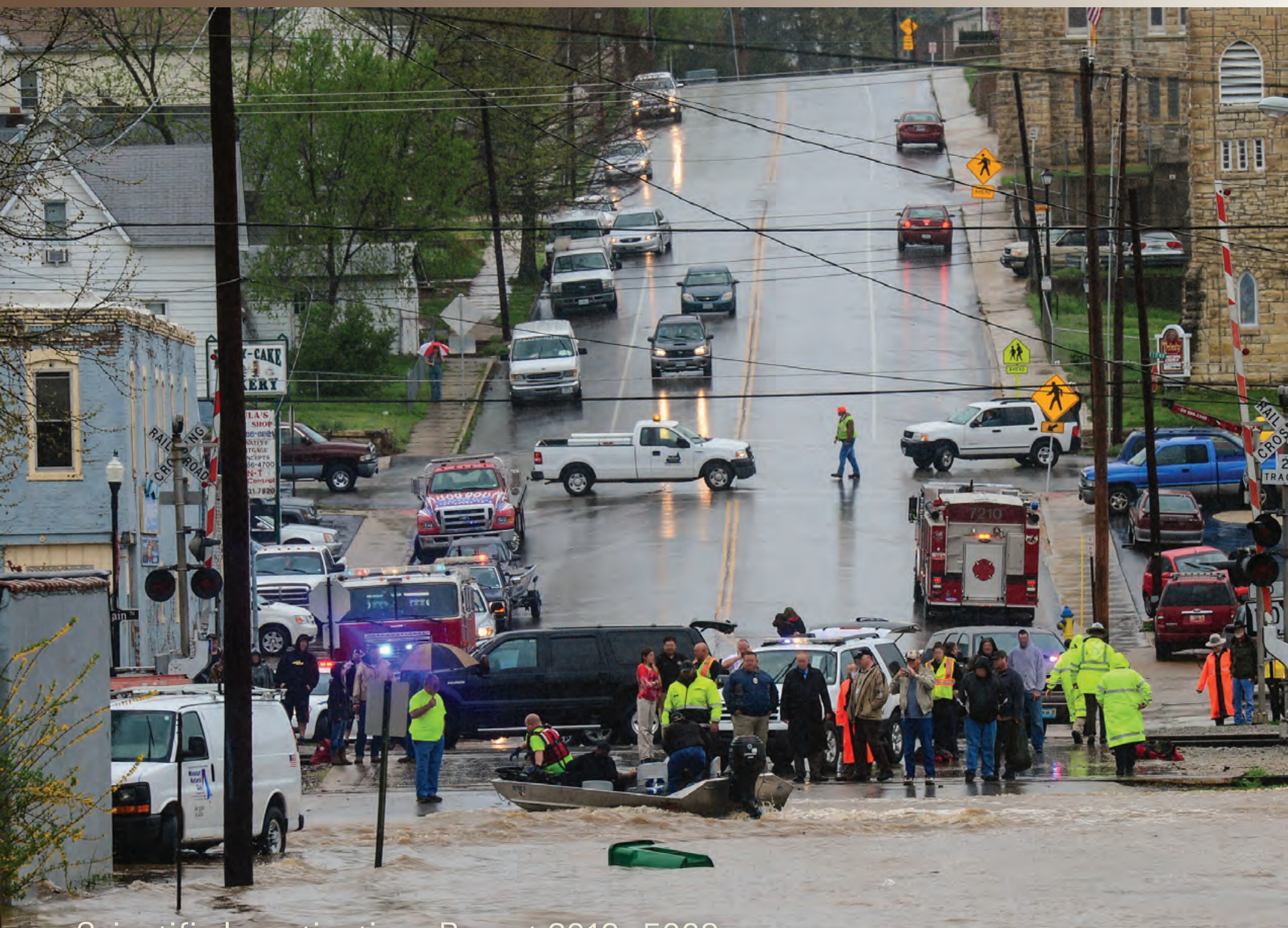

Scientific Investigations Report 2019-5068

U.S. Department of the Interior

U.S. Geological Survey 
Cover: Flooding on Joachim Creek at De Soto, Missouri, looking west from East Miller Street toward West Miller and Main streets.

Back: Flooded cars and business at 519 East Main Street. Looking west to Hopson Field at newly constructed bridge. Photographs courtesy of Leader Publications, April 18, 2013. Ted Howell, photographer. 


\section{Flood-Inundation Maps for Joachim Creek, De Soto, Missouri, 2018}

By David C. Heimann, Jonathan D. Voss, and Paul H. Rydlund, Jr.

Prepared in cooperation with the city of De Soto, Missouri, and Jefferson County, Missouri

Scientific Investigations Report 2019-5068 


\title{
U.S. Department of the Interior DAVID BERNHARDT, Secretary
}

\author{
U.S. Geological Survey \\ James F. Reilly II, Director
}

U.S. Geological Survey, Reston, Virginia: 2019

For more information on the USGS - the Federal source for science about the Earth, its natural and living resources, natural hazards, and the environment-visit https://www.usgs.gov or call 1-888-ASK-USGS.

For an overview of USGS information products, including maps, imagery, and publications, visit https://store.usgs.gov.

Any use of trade, firm, or product names is for descriptive purposes only and does not imply endorsement by the U.S. Government.

Although this information product, for the most part, is in the public domain, it also may contain copyrighted materials as noted in the text. Permission to reproduce copyrighted items must be secured from the copyright owner.

Suggested citation:

Heimann, D.C., Voss, J.D., and Rydlund, P.H., Jr., 2019, Flood-inundation maps for Joachim Creek, De Soto, Missouri, 2018: U.S. Geological Survey Scientific Investigations Report 2019-5068, 10 p., https://doi.org/10.3133/sir20195068.

ISSN 2328-0328 (online) 


\section{Acknowledgments}

The authors wish to thank the city of De Soto, Missouri, and Jefferson County, Missouri, for support in the development of flood-inundation maps and the operation and maintenance of the streamgage used for this study. The authors also wish to acknowledge the Citizens Committee for Flood Relief in De Soto, Missouri, for their continued interest and support of the U. S. Geological Survey flood-inundation mapping efforts along Joachim Creek. The authors acknowledge Wood Environment and Infrastructure Solutions for providing the original hydraulic model used in this study. Special thanks are given to the National Weather Service for their continued support of the U.S. Geological Survey Flood Inundation Mapping Program. 



\section{Contents}

Acknowledgments ……...................................................................................................................

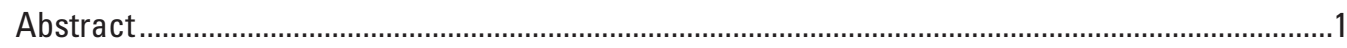

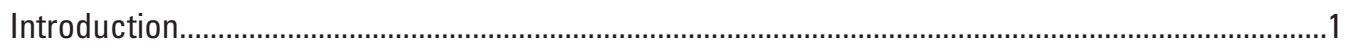

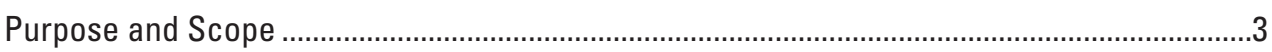

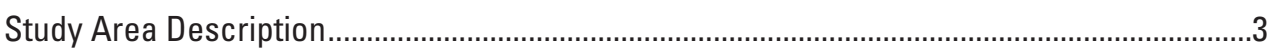

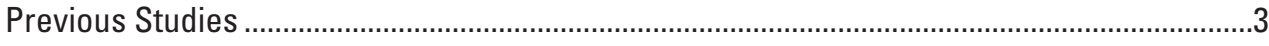

Creation of Flood-Inundation-Map Library …….........................................................................

Computation of Water-Surface Profiles.................................................................................

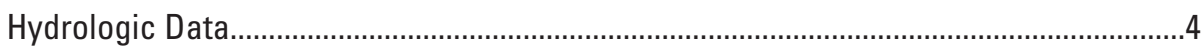

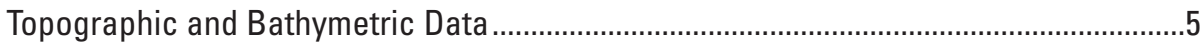

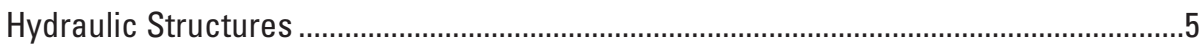

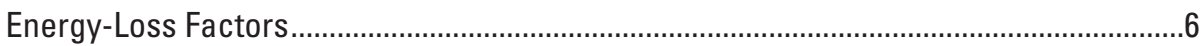

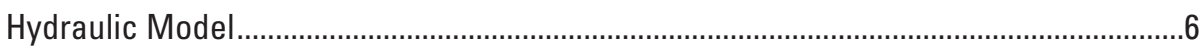

Development of Water-Surface Profiles ............................................................................

Development of Flood-Inundation Maps ………….............................................................

Flood-Inundation Map Delivery ....................................................................................

Disclaimer for Flood-Inundation Maps ............................................................................

Uncertainties and Limitations Regarding Use of Flood-Inundation Maps .......................7

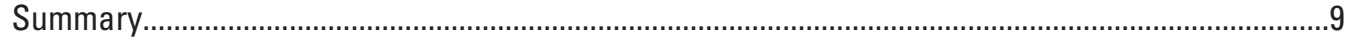

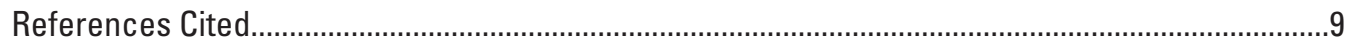

\section{Figures}

1. Map showing location of the study reach, elevation cross sections used in the hydraulic model, and location of the cooperative U.S. Geological Survey streamgage Joachim Creek at De Soto, Missouri ..............................................................2

2. Flood-inundation map for Joachim Creek, De Soto, Missouri, corresponding to a stage of 17.0 feet at the U.S. Geological Survey streamgage 07019500

\section{Tables}

1. U.S. Geological Survey streamgage information for Joachim Creek at De Soto, Missouri.

2. Peak discharges for selected annual exceedance probabilities for Joachim Creek at De Soto, Missouri.

3. Estimated discharges for corresponding stages and water-surface elevations at the streamgage Joachim Creek at De Soto, Missouri, used in the hydraulic model for the study reach

4. Calibration of model to target in-channel water-surface elevations at U.S. Geological Survey streamgage Joachim Creek at De Soto, Missouri.

5. Calibration of model to water-surface elevations at selected locations along Joachim Creek for the flood of April 18, 2013. 


\section{Conversion Factors}

U.S. customary units to International System of Units

\begin{tabular}{lll}
\hline \multicolumn{1}{c}{ Multiply } & \multicolumn{1}{c}{ By } & \multicolumn{1}{c}{ To obtain } \\
\hline \multicolumn{2}{c}{ Length } \\
\hline foot $(\mathrm{ft})$ & 0.3048 & meter $(\mathrm{m})$ \\
mile $(\mathrm{mi})$ & 1.609 & kilometer $(\mathrm{km})$ \\
\hline \multicolumn{2}{c}{ Area } \\
\hline square mile $\left(\mathrm{mi}^{2}\right)$ & 2.590 & square kilometer $\left(\mathrm{km}^{2}\right)$ \\
\hline \multicolumn{2}{c}{ Flow rate } \\
\hline cubic foot per second $\left(\mathrm{ft}^{3} / \mathrm{s}\right)$ & 0.02832 & cubic meter per second $\left(\mathrm{m}^{3} / \mathrm{s}\right)$ \\
\hline
\end{tabular}

\section{Datum}

Vertical coordinate information is referenced to (1) stage, the height above an arbitrary datum established at a streamgage, and (2) elevation, the height above the North American Vertical Datum of 1988 (NAVD 88).

Horizontal coordinate information is referenced to the North American Datum of 1983 (NAD 83). 


\title{
Flood-Inundation Maps for Joachim Creek, De Soto, Missouri, 2018
}

\author{
By David C. Heimann, Jonathan D. Voss, and Paul H. Rydlund, Jr.
}

\section{Abstract}

Digital flood-inundation maps for a 6.7-mile reach of Joachim Creek, De Soto, Missouri, were created by the U.S. Geological Survey (USGS) in cooperation with the city of De Soto and Jefferson County, Missouri. The flood-inundation maps, which can be accessed through the USGS Flood Inundation Mapping Program website at https://www.usgs. gov/mission-areas/water-resources/science/flood-inundationmapping-fim-program, depict estimates of the areal extent and depth of flooding corresponding to selected water levels (stages) at the USGS streamgage Joachim Creek at De Soto, Missouri (station number 07019500). Near-real-time stages at this streamgage may be obtained on the internet from the USGS National Water Information System at https://waterdata. usgs.gov/nwis or the National Weather Service Advanced Hydrologic Prediction Service at http:/water.weather.gov/ ahps $2 /$ hydrograph.php? wfo $=$ lsx \&gage $=$ desm 7 , which also forecasts flood hydrographs at this site (site DESM7).

Flood profiles were computed for the stream reach using a one-dimensional model for simulation of water-surface profiles with steady-state (gradually varied) or unsteady-state flow computation options. The model was calibrated by using the theoretical stage-discharge relation at the USGS streamgage Joachim Creek at De Soto, Missouri (station number 07019500), and documented high-water marks from the flood of April 18, 2013.

The hydraulic model was then used to compute 10 watersurface profiles for flood stages at 1-foot (ft) intervals referenced to the streamgage datum. The profiles ranged from $8.0 \mathrm{ft}$, or near bankfull, to $17.0 \mathrm{ft}$, which exceeds the stage that corresponds to the estimated 0.2-percent annual exceedance probability flood (500-year recurrence interval flood). The simulated water-surface profiles were then combined with a geographic information system digital elevation model (derived from light detection and ranging data having a $0.60-\mathrm{ft}$ vertical accuracy and 1.97-ft horizontal resolution) to delineate the area flooded at each water level.

The availability of these maps, along with internet information regarding current stage from the USGS streamgage and forecasted high-flow stages from the National Weather Service, will provide emergency management personnel and residents with information that is critical for flood-response activities such as evacuations and road closures and for postflood recovery efforts.

\section{Introduction}

During April 2013, May 2013, August 2016, and April 2017 , the residents of the city of De Soto, Missouri, population 6,380 (U.S. Census Bureau, 2019) have experienced substantial flooding from Joachim Creek (fig. 1). Flooding in April 2013 resulted in the death of one individual by drowning, and the first responders also are at direct risk because the rural firehouse is in the flood plain. The residents of De Soto lack the resources needed to determine the status and consequences of water levels (stages) and streamflows along Joachim Creek, including flood conditions that threaten lives and property.

Prior to this study, emergency responders in De Soto, Missouri, relied on several information sources (all of which are available on the internet) to make decisions on how to best alert the public and mitigate flood damages. One source is the Federal Emergency Management Agency (FEMA) flood insurance study (FIS) for De Soto, Missouri, dated April 2006 (FEMA, 2006). A second source of information is the U.S. Geological Survey (USGS) streamgage Joachim Creek at De Soto, Missouri, from which current (USGS, 2018a) and historical (since July 7, 2018) water levels and discharges can be obtained. A third source of flood-related information is the National Weather Service (NWS) Advanced Hydrologic Prediction Service (AHPS), which displays the USGS stage data from the streamgage and also issues forecasts of stage at the Joachim Creek at De Soto, Missouri, streamgage (NWS, 2018a).

Although the current stage at a USGS streamgage is particularly useful for residents in the immediate vicinity of a streamgage, the current stage is of limited use to residents farther upstream or downstream because the water-surface elevation is not constant along the stream reach. Knowledge of a water level at a streamgage is difficult to translate into depth and areal extent of flooding at points distant from the streamgage. One way to address these informational gaps is to 


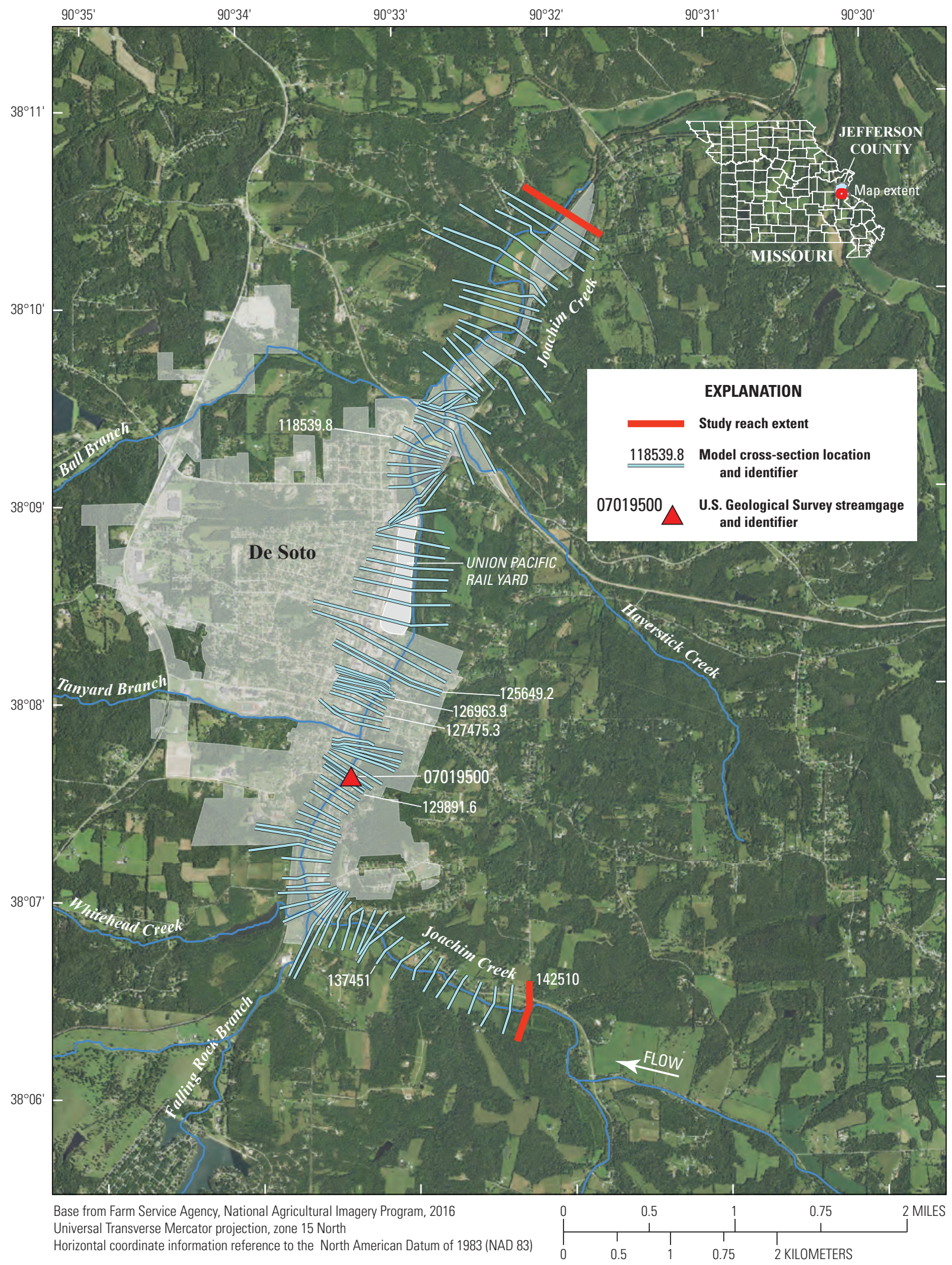

Figure 1. Location of the study reach, elevation cross sections used in the hydraulic model, and location of the cooperative U.S. Geological Survey streamgage Joachim Creek at De Soto, Missouri (station number 07019500). 
produce a library of flood-inundation maps that are referenced to the stages recorded at the USGS streamgage. By referring to the appropriate map, emergency responders can discern the severity of flooding (depth of water and areal extent), identify roads that are or will soon be flooded, and make plans for notification or evacuation of residents in harm's way for some distance upstream and downstream from the streamgage. In addition, the capability to visualize the potential extent of flooding has helped to motivate residents to take precautions and heed warnings that they previously might have disregarded. In 2018-19, the USGS, in cooperation with the city of De Soto, Missouri, and Jefferson County, Missouri, led a project to produce a library of flood-inundation maps for Joachim Creek, De Soto, Missouri.

\section{Purpose and Scope}

The purpose of this report is to describe the development of a series of estimated flood-inundation maps for Joachim Creek, De Soto, Missouri, to identify where the maps are on the internet, and how the ancillary data (geographic information system [GIS] flood polygons and depth grids) can be downloaded. The 6.7-mile study reach extends from 1.3 miles upstream from the De Soto, Missouri, city boundary downstream to the approximate boundary of De Soto (fig. 1). The maps were produced for flood levels referenced to the stage recorded at the USGS streamgage Joachim Creek at De Soto, Missouri (station number 07019500; table 1); the gage is approximately 2.4 miles downstream from the upstream extent of the study reach (fig. 1).

The maps cover a range in stage from 8.0 to 17.0 feet (ft), referenced to the streamgage datum. The 8.0 - $\mathrm{ft}$ stage is approximately bankfull and is defined by the NWS (2018b) as the "action stage" or that stage, when reached by a rising stream, requires the NWS or a partner to take some type of mitigation action in preparation for possible significant hydrologic activity. The 17.0-ft stage exceeds the stage that corresponds to the estimated 0.2-percent annual exceedance probability flood (500-year recurrence interval).

\section{Study Area Description}

The Joachim Creek study reach is in east-central Missouri in Jefferson County and is within the city limits of De Soto, Missouri (fig. 1). The drainage area upstream from the USGS streamgage at De Soto is 42.4 square miles, and the drainage area at the downstream extent of the study reach is 60.8 square miles. The Joachim Creek study basin is in the Ozark Plateau physiographic region (Fenneman, 1938). Land slopes in the basin are generally 3 to 10 percent with local relief of 300 to $400 \mathrm{ft}$ (Collier, 1955). The primary land cover of the study basin is forest ( 71 percent) followed by pasture (12 percent), based on 2011 National Land Cover Data (Homer and others, 2015). Less than 5 percent of the basin is classified as low- to high-intensity development. The study reach is 6.7 miles with an average top-of-bank width of $560 \mathrm{ft}$ and average slope of 11.4 feet per mile based on channel cross-section data obtained from a hydraulic model of Joachim Creek (Alecia Williams, Wood Environment and Infrastructure Solutions, written commun., 2018). There are seven bridge crossings in the main-stem reach, which include one railroad, three state highway, and three county/city road crossings.

\section{Previous Studies}

The hydrologic and hydraulic analyses for the latest published FIS for Jefferson County, Missouri, (FEMA, 2006) includes hydraulic analysis for Joachim Creek, De Soto, Missouri, which was completed by the U.S. Army Corps of Engineers (USACE), St. Louis District, in August 2002 (FEMA, 2002). A previous FIS for De Soto, Missouri, was completed in 1981 by Booker Associates, Inc., (FEMA, 1981) and revised by FEMA in 1998 (FEMA, 2006). An updated

Table 1. U.S. Geological Survey streamgage information for Joachim Creek at De Soto, Missouri.

[Station location is shown in figure 1. $\mathrm{mi}^{2}$, square mile; ft, foot; NAVD 88, North American Vertical Datum of 1988 ; $\mathrm{ft}^{3} / \mathrm{s}$, cubic foot per second; ${ }^{\circ}$, degree; ', minute; ", second]

\begin{tabular}{|c|c|c|c|c|c|c|c|}
\hline Station name & $\begin{array}{l}\text { Station } \\
\text { number }\end{array}$ & $\begin{array}{l}\text { Drainage } \\
\text { area } \\
\left(\mathrm{mi}^{2}\right)\end{array}$ & Latitude & Longitude & $\begin{array}{l}\text { Period of peak- } \\
\text { flow record } \\
\text { (water year) }^{1}\end{array}$ & $\begin{array}{l}\text { Maximum recorded stage, } \\
\text { (ft), } \\
\text { gage datum and elevation } \\
\text { (ft, NAVD 88) } \\
\text { and date }\end{array}$ & $\begin{array}{c}\text { Maximum discharge } \\
\left(\mathrm{ft}^{3} / \mathrm{s}\right) \\
\text { and date }\end{array}$ \\
\hline $\begin{array}{l}\text { Joachim Creek } \\
\text { at De Soto, } \\
\text { Missouri }\end{array}$ & 07019500 & 42.4 & $38^{\circ} 07^{\prime} 36^{\prime \prime}$ & $90^{\circ} 33^{\prime} 23^{\prime \prime}$ & 2018 & $\begin{array}{c}{ }^{2} 14.3 \\
(506.2) \\
\text { April 18, } 2013\end{array}$ & $\begin{array}{c}{ }^{3} 15,000 \\
\text { April 18, } 2013\end{array}$ \\
\hline
\end{tabular}

\footnotetext{
${ }^{1}$ Water year is the 12-month period from October 1 of one year through September 30 of the following year and is designated by the calendar year in which it ends.

${ }^{2}$ Stage interpolated from observed high-water marks.

${ }^{3}$ Discharge estimated using hydraulic model and observed high-water marks.
} 
hydraulic model was completed in July 2015 by Wood

Environmental and Infrastructure Solutions (Alecia Williams, Wood Environment and Infrastructure Solutions, written commun., 2018) in an ongoing effort to revise the FIS for De Soto, Missouri.

The latest published FIS (FEMA, 2006) presents estimates of the peak discharges and associated annual exceedance probabilities (AEPs) and their associated water-surface elevations at several locations along Joachim Creek. Updated peak discharges for AEPs of 10, 2, 1, and 0.2 percent (table 2) at the Joachim Creek at De Soto, Missouri, streamgage were generated for this study using the USGS StreamStats application (USGS, 2018c).

\section{Creation of Flood-Inundation-Map Library}

The USGS has standardized the procedures for creating flood-inundation maps for flood-prone communities (USGS, 2018c) so that the process followed and products produced are similar regardless of which USGS office is responsible for the work. Tasks specific to the development of the flood maps for this study included (1) installation of the streamgage Joachim Creek at De Soto, Missouri (table 1); (2) acquisition of a hydraulic model that is being used for an ongoing update of the FIS for De Soto, Missouri (Alicia Williams, Wood Environmental and Infrastructure Solutions, written commun., 2018); (3) calibration of energy-loss factors (roughness coefficients) in the stream channel and flood plain and determination of steady-flow data; (4) computation of water-surface profiles using the USACE Hydrologic Engineering Center's River Analysis System (HEC-RAS) computer program (USACE, 2016); (5) production of estimated flood-inundation maps for selected stream stages using the USACE Hydrologic Engineering Center's Geospatial River Analysis System (HECGeoRAS) computer program (Ackerman, 2009) and a GIS; and (6) preparation of the maps as shapefile polygons that depict the areal extent of flood inundation at various stages and as depth grids that provide the depth of floodwaters for display on a USGS flood-inundation mapping application.

\section{Computation of Water-Surface Profiles}

The hydraulic model used in this study was developed in 2015 for an ongoing update of the FIS for De Soto, Missouri (Alecia Williams, Wood Environment and Infrastructure Solutions, written commun., 2018). This model, which was developed using HEC-RAS, version 4.1 (USACE, 2010), was calibrated by the USGS and used to produce the 10 floodinundation maps in this study using HEC-RAS version 5.0.3 (USACE, 2016). HEC-RAS is a one-dimensional model for simulation of water-surface profiles with steady-state (gradually varied) or unsteady-state flow computation options.

\section{Hydrologic Data}

The study reach includes one USGS streamgage (station number 07019500; fig. 1; table 1) established for this project. Stage is measured every 15 minutes, transmitted hourly by a satellite radio in the streamgage, and made available on the internet through the USGS National Water Information System (NWIS; USGS, 2018b). Stage data from this streamgage are referenced to a local datum but can be converted to watersurface elevations referenced to the North American Vertical Datum of 1988 (NAVD 88) by adding $491.90 \mathrm{ft}$. Continuous records of discharge are computed from a stage-discharge relation (Turnipseed and Sauer, 2010), which has been developed for the streamgage, and are available through the USGS NWIS website.

The estimated discharges used for specific stages in the model simulations (table 3 ) were obtained from a theoretical stage-discharge rating (Turnipseed and Sauer, 2010) at the streamgage location generated from discrete streamflow measurements and simulated peak discharges derived from the calibrated hydraulic model corresponding to the AEPs provided in table 2 (see "Hydraulic Model" section). No major tributaries join Joachim Creek within the 6.7-mile study reach; therefore, the streamgage-derived discharges were not adjusted for tributary inflows but were held constant throughout the study reach for a given profile.

Table 2. Peak discharges for selected annual exceedance probabilities for Joachim Creek at De Soto, Missouri.

[Data from U.S. Geological Survey StreamStats application (USGS, 2018c). $\mathrm{mi}^{2}$, square mile; $\mathrm{ft}^{3} / \mathrm{s}$, cubic foot per second; USGS, U.S. Geological Survey]

\begin{tabular}{|c|c|c|c|c|c|}
\hline \multirow{2}{*}{ Location on Joachim Creek } & \multirow{2}{*}{$\begin{array}{c}\text { Drainage } \\
\text { area } \\
\left(\mathrm{mi}^{2}\right)\end{array}$} & \multicolumn{4}{|c|}{$\begin{array}{l}\text { Estimated discharge }\left(\mathrm{ft}^{3} / \mathrm{s}\right) \\
\text { for indicated annual exceedance probabilities (percent) }\end{array}$} \\
\hline & & 10 & 2 & 1 & 0.2 \\
\hline At upstream end of study reach at Bade Road & 31.4 & 6,780 & 11,500 & 13,500 & 18,300 \\
\hline At USGS streamgage number 07019500 & 42.4 & 8,030 & 13,500 & 15,900 & 21,500 \\
\hline At downstream end of study reach & 60.8 & 9,610 & 16,000 & 18,800 & 25,400 \\
\hline
\end{tabular}


Table 3. Estimated discharges for corresponding stages and water-surface elevations at the streamgage Joachim Creek at De Soto, Missouri, used in the hydraulic model for the study reach.

[ft, foot; NAVD 88, North American Vertical Datum of 1988; $\mathrm{ft}^{3} / \mathrm{s}$, cubic foot per second]

\begin{tabular}{ccc}
\hline $\begin{array}{c}\text { Stage of water-surface profile }{ }^{1} \\
\text { (ft) }\end{array}$ & $\begin{array}{c}\text { Water-surface } \\
\text { elevation } \\
\text { (ft, NAVD 88) }\end{array}$ & $\begin{array}{c}\text { Estimated discharge at streamgage location } \\
\text { for indicated stage }^{2} \\
\mathbf{f t}^{3} / \mathbf{s} \text { ) }\end{array}$ \\
\hline 8.0 & 499.90 & 4,550 \\
9.0 & 500.90 & 5,850 \\
10.0 & 501.90 & 7,300 \\
11.0 & 502.90 & 8,900 \\
12.0 & 503.90 & 10,500 \\
13.0 & 504.90 & 12,600 \\
14.0 & 505.90 & 14,400 \\
15.0 & 506.90 & 16,900 \\
16.0 & 507.90 & 19,200 \\
17.0 & 508.90 & 22,500 \\
\hline
\end{tabular}

${ }^{1}$ Water-surface profiles are 1-foot increments of stage, referenced to the gage datum of the U.S. Geological Survey streamgage Joachim Creek at De Soto, Missouri (station number 07019500).

${ }^{2}$ Discharges corresponding to stages greater than 8 feet were derived from the calibrated model using simulated peak discharges indicated in table 2 .

\section{Topographic and Bathymetric Data}

All topographic data used in this study are referenced vertically to NAVD 88 and horizontally to the North American Datum of 1983. Cross-section elevation data were obtained from a digital elevation model (DEM) that was derived from light detection and ranging (lidar) data that were collected during December 2010 by Surdex Corporation, Chesterfield, Missouri, through a contract with the USACE, St. Louis Division. Postprocessing of these data was completed by Surdex Corporation on April 6, 2011 (Missouri Spatial Data Information Service, 2018). The bare-earth lidar data were processed using USGS Base Lidar Specifications version 1.3 (Heidemann, 2018) that met or exceeded the National Map Accuracy standards for vertical and horizontal accuracy guidelines for 2-ft contours (American Society for Photogrammetry and Remote Sensing [ASPRS], 1990, 2004). The lidar data have a horizontal accuracy of $1.97 \mathrm{ft}$ (60 centimeters) root mean squared error (RMSE) and vertical accuracy of $0.607 \mathrm{ft}$ (18.5 centimeters) RMSE. The final DEM, which was resampled to a 3.28-ft grid-cell size to decrease the GIS processing time, has a vertical accuracy of plus or minus $1 \mathrm{ft}$.

Any development or landscape modifications within the Joachim Creek flood plain that took place after the lidar was flown (December 2010) and that could result in substantial topographic and hydraulic changes to the flood plain, were considered for inclusion in the DEM. Modifications within the Union Pacific rail yard in De Soto (fig. 1) were considered but were based on the February 19, 2016, site development package (TranSystems, 2016). The modifications within the De Soto rail yard generally were within the stated contour accuracy of the original lidar-based DEM and, therefore, were not included in the final DEM.

By using HEC-GeoRAS (Ackerman, 2009), a set of procedures, tools, and utilities for processing geospatial data in ArcGIS, elevation data were extracted from the DEM for 97 cross sections (fig. 1) and subsequently input to the HEC-RAS model. Because lidar data cannot provide ground elevations below a stream's water surface, channel cross sections in the HEC-RAS model were surveyed by Wood Environment and Infrastructure Solutions during 2015 (Alicia Williams, Wood Environment and Infrastructure Solutions, written commun., 2018) and spot verified by USGS field crews during 2018. Cross-sectional depths were measured by wading at all crosssection locations. A differential global positioning system with real-time kinematic technology was used to derive horizontal locations and the elevation of the water surface at each surveyed cross section.

\section{Hydraulic Structures}

Seven structures, consisting of six road crossings (three county road bridges and three state highway bridges) and one railroad bridge have the potential to affect water-surface elevations during floods along the stream. Bridge-geometry data were obtained from a HEC-RAS model developed by Wood Environment and Infrastructure Solutions (Alicia Williams, Wood Environment and Infrastructure Solutions, written commun., 2018), and the data were verified by field surveys and from as-built bridge plans by personnel from the USGS Central Midwest Water Science Center. 


\section{Energy-Loss Factors}

Hydraulic analyses require the estimation of energy losses that result from frictional resistance exerted by a channel on flow. These energy losses are quantified by the Manning's roughness coefficient (" $n$ " value). Initial (precalibration) $n$ values were selected on the basis of field observations, high-resolution aerial photographs (Farm Service Agency, 2012), and tabulated estimates of $n$ values (Chow, 1959).

As part of the calibration process, the initial $n$ values were varied by flow and adjusted until the differences between simulated and observed water-surface elevations at the streamgage and elsewhere along the study reach were minimized. The final $n$ values ranged from 0.022 to 0.045 for the main channel and from 0.03 to 0.12 for the overbank areas modeled in this analysis. The lowest channel coefficients were placed in straight bedrock-lined reaches and the highest were placed in low-gradient, fine-material substrate reaches with vegetated banks. The lowest flood plain coefficients were placed in open fields and the highest in densely forested areas.

\section{Hydraulic Model}

The HEC-RAS analysis for this study was done by using the steady-state flow computation option. Steady-state flow data consisted of flow regime, boundary conditions, and peak flows that produced water-surface elevations at the streamgage cross section that matched target water-surface elevations. These target elevations coincided with $1 \mathrm{ft}$ increments of stage, referenced to the local gage datum. Subcritical (tranquil) flow regime was assumed for the simulations. Normal depth, based on an estimated average water-surface slope of 0.003 , was used as the reach's downstream boundary condition. The peak flows that were used in the model were discussed in the section, "Hydrologic Data."

The HEC-RAS model was calibrated to a theoretical developed stage-discharge relation at the Joachim Creek at De Soto, Missouri, streamgage and to documented high-water marks from the flood of April 18, 2013. Model calibration was accomplished by adjusting Manning's $n$ values until the results of the hydraulic computations closely agreed with the observed water-surface elevations for given flows. Differences between target and modeled water-surface elevations for two simulated flows at the USGS streamgage were equal to or less than $0.49 \mathrm{ft}$ (table 4). Differences between surveyed and modeled elevations of seven high-water marks in the study reach for the flood of April 18, 2013, were less than or equal to $0.52 \mathrm{ft}$ (table 5). The results demonstrate that the model is capable of simulating accurate water levels over a range of stages and flows in the reach.

Table 4. Calibration of model to target in-channel water-surface elevations at U.S. Geological Survey streamgage Joachim Creek at De Soto, Missouri (station number 07019500).

[ft, foot; NAVD 88, North American Vertical Datum of 1988]

\begin{tabular}{cccc}
\hline $\begin{array}{c}\text { Stage of water-surface profile } \\
\text { (ft) }\end{array}$ & $\begin{array}{c}\text { Target water-surface elevation } \\
\text { (ft, NAVD 88) }\end{array}$ & $\begin{array}{c}\text { Modeled water-surface elevation } \\
\text { (ft, NAVD 88) }\end{array}$ & $\begin{array}{c}\text { Difference in elevation } \\
\text { (ft) }\end{array}$ \\
\hline 7 & 498.90 & 499.29 & -0.39 \\
8 & 499.90 & 500.39 & -0.49 \\
\hline
\end{tabular}

Table 5. Calibration of model to water-surface elevations at selected locations along Joachim Creek for the flood of April 18, 2013 (streamgage stage of $14.3 \mathrm{ft}$ ).

[ft, foot; NAVD 88, North American Vertical Datum of 1988]

\begin{tabular}{cccc}
\hline $\begin{array}{c}\text { Cross-section identifier } \\
\text { (ft) }\end{array}$ & $\begin{array}{c}\text { Surveyed water-surface elevation } \\
\text { (ft, NAVD 88) }\end{array}$ & $\begin{array}{c}\text { Modeled water-surface elevation } \\
\text { (ft, NAVD 88) }\end{array}$ & $\begin{array}{c}\text { Difference in elevation } \\
\text { (ft) }\end{array}$ \\
\hline 118539.8 & 481.76 & 481.28 & 0.48 \\
125649.2 & 496.85 & 496.36 & 0.49 \\
126963.9 & 501.03 & 501.55 & -0.52 \\
127475.3 & 501.96 & 502.07 & -0.11 \\
129891.6 & 507.77 & 507.65 & 0.12 \\
137451 & 527.56 & 527.43 & 0.13 \\
142510 & 543.10 & 543.21 & -0.11 \\
\hline
\end{tabular}

${ }^{1}$ Cross-section identification numbers are referenced to the longitudinal baseline used in the hydraulic model. 


\section{Development of Water-Surface Profiles}

The calibrated hydraulic model was used to generate water-surface profiles for 10 stages at 1-ft intervals between 8.0 and $17.0 \mathrm{ft}$ as referenced to the local datum of the Joachim Creek at De Soto, Missouri, streamgage. These stages correspond to elevations of 499.9 and $508.9 \mathrm{ft}$, NAVD 88, respectively. Discharges corresponding to the various stages were obtained from a theoretical stage-discharge rating generated from discrete streamflow measurements and simulated peak discharges corresponding to the AEPs provided in table 2 .

\section{Development of Flood-Inundation Maps}

Flood-inundation maps were created for the Joachim Creek study reach and referenced to the USGS streamgage Joachim Creek at De Soto, Missouri (station number 07019500), which has been designated as a NWS floodforecast point (site DESM7) as of 2018 (NWS, 2018a). The DEM data were derived from the same lidar data described previously in the section "Topographic and Bathymetric Data" and, therefore, have an estimated vertical accuracy of $2 \mathrm{ft}$ (that is, plus or minus $1 \mathrm{ft}$ ). Estimated flood-inundation boundaries for each simulated profile were developed with HEC-GeoRAS software (Ackerman, 2009), which allows the preparation of geometric data for import into HEC-RAS and processes simulation results exported from HEC-RAS (USACE, 2010). Shapefile polygons and depth grids of the inundated areas for each profile were modified, as required, in the ArcMap application of ArcGIS (Esri, 2018) to ensure a hydraulically reasonable transition of the flood boundaries between modeled cross sections.

Any inundated areas that were detached from the main channel were examined to identify subsurface connections with the main river, such as through culverts under roadways. Where such connections existed, the mapped inundated areas were retained in their respective flood maps; otherwise, the erroneously delineated parts of the flood extent were deleted. The flood-inundation areas are overlaid on high-resolution, georeferenced, aerial photographs of the study area. Bridge surfaces are shown as not inundated until the lowest flood stage that either exceeds the bridge deck or completely inundates both approaches to the bridge. In these latter circumstances, the bridge surface is depicted as being inundated. Estimates of water depth can be obtained from the depth-grid data (Heimann and others, 2019) that are included with the presentation of the flood maps on an interactive USGS mapping application described in the following section, "FloodInundation Map Delivery." The flood map corresponding to the highest simulated water-surface profile, a stage of $17.0 \mathrm{ft}$, is presented in figure 2 .

\section{Flood-Inundation Map Delivery}

The current study documentation is available online at the USGS Publications Warehouse (https://doi.org/10.5066/ P9MD7KUL). Also, a Flood Inundation Mapping Program website (USGS, 2018d) has been established to make USGS flood-inundation study information available to the public. The website links to a mapping application that presents map libraries and provides detailed information on flood extents and depths for modeled sites. The mapping application enables the production of customized flood-inundation maps from the map library for Joachim Creek, De Soto, Missouri (Heimann and others, 2019). A link on the mapping application website connects to the USGS NWIS (USGS, 2018a), which presents the current stage and streamflow at the USGS streamgage Joachim Creek at De Soto, Missouri (station number 07019500), to which the inundation maps are referenced. A second link connects to the NWS AHPS site (NWS, 2018a) so that the user can obtain applicable information on forecasted peak stage. The estimated flood-inundation maps are displayed in sufficient detail so that preparations for flooding and decisions for emergency response can be performed efficiently. Depending on the flood magnitude, roadways are shown as shaded (inundated and likely impassable) or not shaded (dry and passable) to facilitate emergency planning and use. Bridges are shaded - that is, shown as inundated - when the flood stage exceeds the elevation of the bridge deck or that of both approaches to the bridge. A shaded building should not be interpreted to mean that the structure is completely submerged but, rather, that bare-earth surfaces in the vicinity of the building are inundated. In these instances, the water depth (as indicated in the mapping application by holding the cursor over an inundated area) near the building would be an estimate of the water level inside the structure, unless flood-proofing measures had been implemented.

\section{Disclaimer for Flood-Inundation Maps}

The flood-inundation maps should not be used for navigation, regulatory, permitting, or other legal purposes. The USGS provides these maps "as is" for a quick reference, emergency planning tool but assumes no legal liability or responsibility resulting from the use of this information.

\section{Uncertainties and Limitations Regarding Use of Flood-Inundation Maps}

Although the flood-inundation maps represent the boundaries of inundated areas with a distinct line, some uncertainty is associated with these maps. The flood boundaries shown were estimated on the basis of water stages and streamflows at selected USGS streamgages. Water-surface elevations along the stream reaches were estimated by steady-state hydraulic modeling, assuming unobstructed flow, and used discharges and hydrologic conditions anticipated at the USGS 


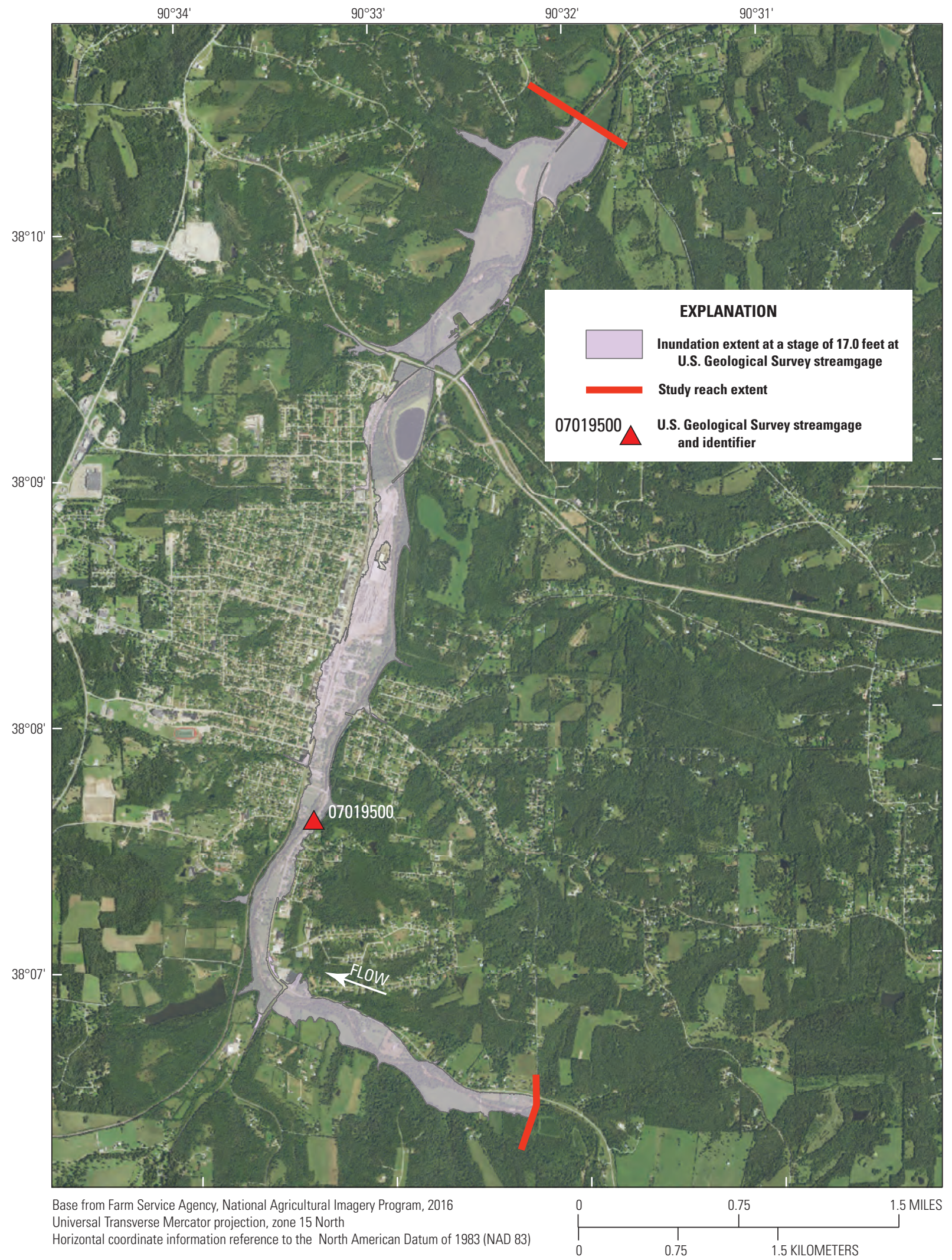

Figure 2. Flood-inundation map for Joachim Creek, De Soto, Missouri, corresponding to a stage of 17.0 feet at the U.S. Geological Survey streamgage 07019500. 
streamgage. The hydraulic model reflects the land-cover characteristics and any bridge, dam, levee, or other hydraulic structures existing as of July 2015. Unique meteorological factors (timing and distribution of precipitation) may cause actual streamflows along the modeled reach to vary from those assumed during a flood, which may lead to deviations in the water-surface elevations and inundation boundaries shown. Additional areas may be flooded because of unanticipated conditions such as changes in the streambed elevation or roughness, backwater into major tributaries along a main stem river, or backwater from localized debris or ice jams. The accuracy of the floodwater extent portrayed on these maps will vary with the accuracy of the digital elevation model used to simulate the land surface.

If this series of flood-inundation maps will be used in conjunction with NWS river forecasts, the user should be aware of additional uncertainties that may be inherent or factored into NWS forecast procedures. The NWS uses forecast models to estimate the quantity and timing of water flowing through selected stream reaches in the United States. These forecast models (1) estimate the amount of runoff generated by precipitation and snowmelt, (2) simulate the movement of floodwater as it proceeds downstream, and (3) predict the flow and stage (and water-surface elevation) for the stream at a given location (AHPS forecast point) throughout the forecast period (every 6 hours and in many cases, 3 to 5 days into the future). For more information on AHPS forecasts, please see: http://water.weather.gov/ahps/pcpn_and_river_forecasting.pdf.

\section{Summary}

A series of digital flood-inundation maps were developed in cooperation with the city of De Soto, Missouri, and Jefferson County, Missouri, for Joachim Creek, De Soto, Missouri. The maps cover a reach about 6.7 miles long corresponding to the reach limits of Joachim Creek within the De Soto city limits. The maps were developed by using the U.S. Army Corps of Engineers' Hydrologic Engineering Center's River Analysis System (HEC-RAS) and Hydrologic Engineering Center's Geospatial River Analysis System (HEC-GeoRAS) programs to compute water-surface profiles and to delineate estimated flood-inundation areas and depths of flooding for selected stream stages. The HEC-RAS hydraulic model was calibrated to discrete streamflow measurements at the Joachim Creek streamgage and to observed high-water marks from the April 2013 flood. The model was used to compute 10 water-surface profiles for flood stages at 1 -foot (ft) intervals referenced to the streamgage datum and ranging from $8.0 \mathrm{ft}$, or near bankfull, to $17.0 \mathrm{ft}$, which exceeds the stage corresponding to the estimated 0.2 percent annual exceedance probability flood (500-year recurrence interval).

The simulated water-surface profiles were then combined with a geographic information system digital elevation model derived from light detection and ranging data to delineate estimated flood-inundation areas as shapefile polygons and depth grids for each profile. These flood-inundation polygons were overlaid on high-resolution, georeferenced aerial photographs of the study area. The flood maps are available through a mapping application that can be accessed on the USGS Flood Inundation Mapping Science website (https:// www.usgs.gov/mission-areas/water-resources/science/ flood-inundation-mapping-fim-program).

Interactive use of the maps on this mapping application can give users a general indication of depth of water at any point by using the mouse cursor to click within the shaded areas. These maps, in conjunction with the real-time stage data from the U.S. Geological Survey streamgage Joachim Creek at De Soto, Missouri (station number 07019500), and forecasted flood stage data from the National Weather Service Advanced Hydrologic Prediction Service will help guide the general public in taking individual safety precautions and will provide emergency management personnel with a tool to efficiently manage emergency flood operations and postflood recovery efforts.

\section{References Cited}

Ackerman, C.T., 2009, HEC-GeoRAS, GIS tools for support of HEC-RAS using ArcGIS, user's manual, version 4.2: U.S. Army Corps of Engineers, Hydrologic Engineering Center [variously paged].

American Society for Photogrammetry and Remote Sensing [ASPRS], 1990, ASPRS accuracy standards for large-scale maps: accessed December 17, 2018, at http://www.asprs. org/a/society/committees/standards/1990_jul_1068-1070. pdf.

American Society for Photogrammetry and Remote Sensing [ASPRS], 2004, ASPRS guidelines-Vertical accuracy reporting for lidar data: accessed December 17, 2018, at https://www.asprs.org/a/society/committees/standards/Vertical_Accuracy_Reporting_for_Lidar_Data.pdf.

Chow, V.T., 1959, Open-channel hydraulics: New York, McGraw-Hill, 680 p.

Collier, J. E., 1955, Geographic regions of Missouri: Annals of the Association of American Geographers, v. 45, no. 4, p. 368-392.

Esri, 2018, ArcGIS version 10.3.1: accessed October 12, 2018, at http://www.esri.com/software/arcgis/.

Farm Service Agency, 2012, National Agriculture Imagery Program [NAIP] Ortho Imagery of Jefferson County, Missouri: Natural Resources Conservation Service, accessed March 2018 at https://datagateway.nrcs.usda.gov/. 
Farm Service Agency, 2016, National Agriculture Imagery Program [NAIP] Ortho Imagery of Jefferson County, Missouri: Natural Resources Conservation Service, accessed March 2018 at https://datagateway.nrcs.usda.gov/.

Federal Emergency Management Agency [FEMA], 1981, Flood Insurance Study, city of De Soto, Jefferson County, Missouri: Washington D.C.

Federal Emergency Management Agency [FEMA], 2002, Flood Insurance Study, city of De Soto, Jefferson County, Missouri: Washington D.C.

Federal Emergency Management Agency [FEMA], 2006, Flood Insurance Study, Jefferson County, Missouri, and incorporated areas, Volume 1: Washington D.C., 63 p.

Fenneman, N.M., 1938, Physiography of eastern United States: New York, McGraw-Hill Book Co., Inc., 689 p.

Heidemann, H.K., 2018, Lidar base specification (ver. 1.3, February 2018): U.S. Geological Survey Techniques and Methods, book 11, chap. B4, 101 p., https://doi.org/10.3133/ tm11b4.

Heimann, D.C., Voss, J.D., and Rydlund, P. H., Jr., 2019, Geospatial datasets for the flood-inundation study of Joachim Creek, De Soto, Missouri, 2018: U.S. Geological Survey data release, https://doi.org/10.5066/P9MD7KUL.

Homer, Collin G., Dewitz, Jon A., Yang, Limin, Jin, Suming, Danielson, Patrick, Xian, George, Coulston, J., Herold, N.D., Wickham, J.D., Megown, K., 2015, Completion of the 2011 National Land Cover Database for the conterminous United States-Representing a decade of land cover change information: American Society for Photogrammetric Engineering and Remote Sensing, v. 81, no. 5, p. 345-354, accessed May, 2, 2018, at http://www.ingentaconnect.com/ content/asprs/pers/2015/00000081/00000005/art00002.

Missouri Spatial Data Information Service, 2018, Missouri LiDAR DEM download tool: accessed June 5, 2018, at https://msdis.maps.arcgis.com/apps/View/index.html?appid $=350 \mathrm{bcb} 69 \mathrm{dfb} 74 \mathrm{ca} 58 \mathrm{aae} 74 \mathrm{a} 32728 \mathrm{f} 58 \mathrm{~b}$.

National Weather Service [NWS], 2018a, Advanced Hydrologic Prediction Service, Joachim Creek at De Soto, Missouri: accessed November 8, 2018, at http://water.weather. gov/ahps $2 /$ hydrograph.php?wfo=lsx\&gage=desm 7 .

National Weather Service [NWS], 2018b, National Weather Service glossary: accessed November 8, 2018, at http:// w1.weather.gov/glossary/index.php?word=action+stage.

TranSystems, 2016, De Soto Yard Expansion, De Soto, Missouri, Site development package, flood control plans issued for construction, Bulletin no. 1: Kansas City, Mo., TranSystems.
Turnipseed, D.P., and Sauer, V.B., 2010, Discharge measurements at gaging stations: U.S. Geological Survey Techniques and Methods, book 3, chap. A8, 87 p. [Also available at https://pubs.usgs.gov/tm/tm3-a8/.]

U.S. Army Corps of Engineers [USACE], Hydrologic Engineering Center, 2010, HEC-RAS-River analysis system-Hydraulic reference manual (ver. 4.1, January 2010): accessed May 15, 2018, at https://www.hec.usace.army.mil/ software/hec-ras/downloads.aspx.

U.S. Army Corps of Engineers [USACE], Hydrologic Engineering Center, 2016, HEC-RAS-River analysis system-Hydraulic reference manual (ver. 5.0, February 2016): accessed May 15, 2018, at https://www.hec.usace.army.mil/ software/hec-ras/downloads.aspx.

U.S. Census Bureau, 2019, QuickFacts-De Soto, Mo., July 1, 2017, population estimate: accessed February 20, 2019, at https://www.census.gov/quickfacts/fact/table/ desotocitymissouri,US/PST045217.

U.S. Geological Survey [USGS], 2018a, USGS 07019500 Joachim Creek at De Soto, Missouri: U.S. Geological Survey National Water Information System database, accessed August 6, 2018, at https://waterdata.usgs.gov/nwis/uv/?site no $=07019500$.

U.S. Geological Survey [USGS], 2018b, USGS surface-water data for the Nation: U.S. Geological Survey National Water Information System database, accessed August 6, 2018, at https://waterdata.usgs.gov/nwis/sw.

U.S. Geological Survey [USGS], 2018c, USGS StreamStats application: U.S. Geological Survey, accessed November 8, 2018, at https://streamstats.usgs.gov/ss/.

U.S. Geological Survey [USGS], 2018d, USGS Flood Inundation Mapping (FIM) Program: U.S. Geological Survey, accessed December 14, 2018, at https://water.usgs.gov/osw/ flood_inundation.

For more information about this publication, contact: Director, USGS Central Midwest Water Science Center 1400 Independence Road

Rolla, M0 65401

573-308-3667

For additional information, visit: https://www.usgs.gov/centers/cmwater

Publishing support provided by the

Rolla Publishing Service Center 


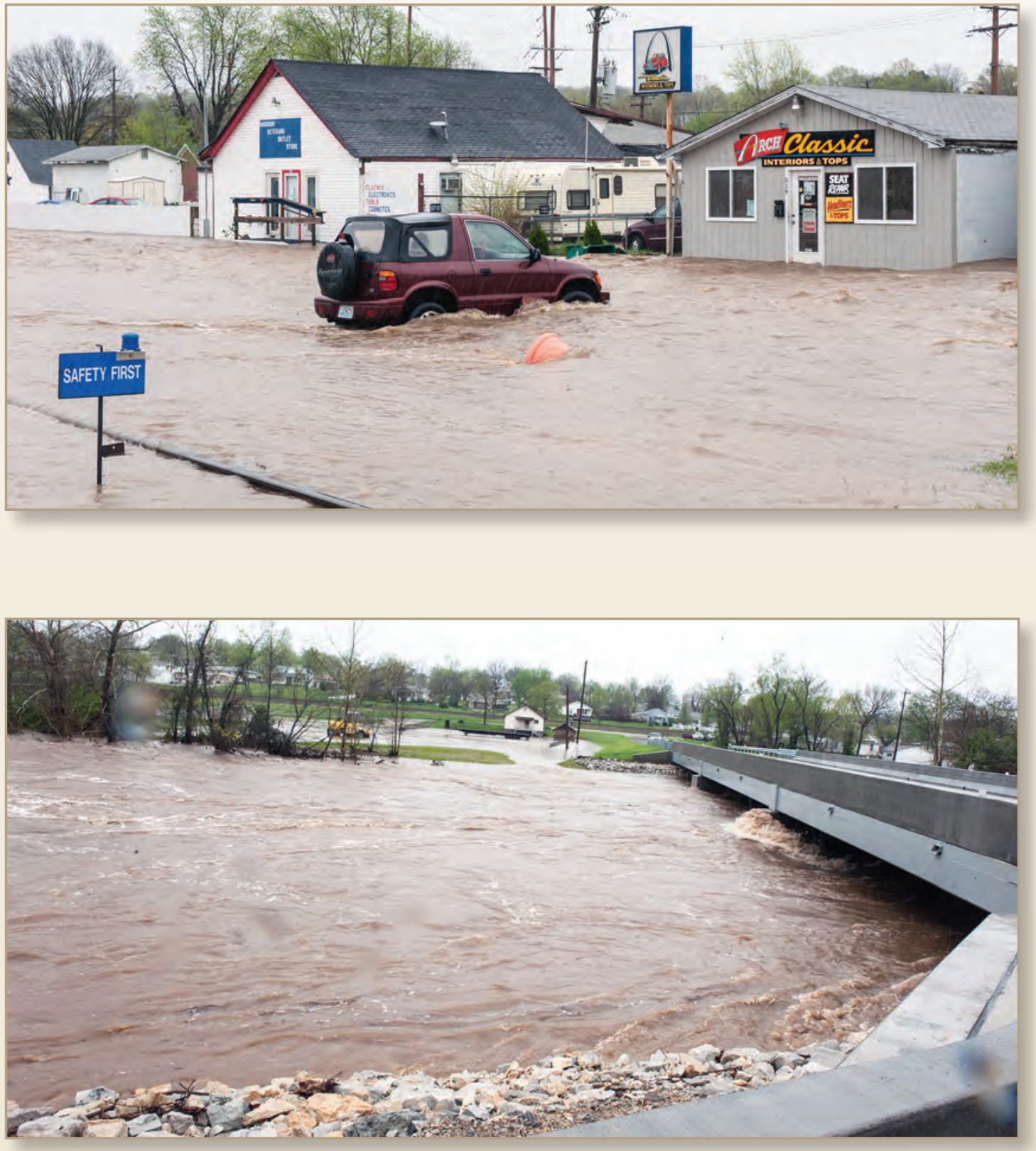